\title{
Exploring the Booking Determinants of the Airbnb Properties: An Example of the Listings of London
}

\begin{abstract}
The aim of this paper is to investigate the factors which influence the probability of an Airbnb property being booked using the properties in London as an example. A binomial logistic model is estimated by sequential Bayesian updating due to the large volume of the data. The results show that, in spite of the market factors revealing great influence, the attributes of the properties play a more important role in influencing the booking probability of the properties. These research findings are potentially beneficial to both the Airbnb practitioners and the industrial organizers.
\end{abstract}

Keywords: Airbnb, Booking Determinants, Binomial Logistic Model, Sequential
Bayesian
Updating,
Big
Data,
Sharing
Economy 


\section{Introduction}

As a pioneer and symbol of the sharing economy in the hospitality industry, Airbnb has enjoyed impressive and sustained growth in the last decade. Airbnb is an online community marketplace for renting accommodations from private individuals. Now it lists more than three million properties covering 65 thousand cities in 191 countries (Airbnb, 2017). Benefitted from the sharing economy based business model, Airbnb enables small businesses and entrepreneurs to compete with traditional "brick and mortar" businesses (Morgan \& Kuch, 2015; Orsi, 2013). However, due to the exponential expansion, it is more and more challenging for the hosts to stand out and be selected by customers among the numerous competitors on the same platform.

The aim of this paper is to investigate the factors which influence the probability of a property being booked using the Airbnb properties in London as an example. Due to the large volume of sample size, sequential Bayesian updating approach is introduced to tourism and hospitality field for the first time. The findings of this study would be valuable and helpful for the current and potential hosts to improve the booking rates and revenue which would be beneficial to the development of Airbnb industry.

\section{Literature Review}

\subsection{Airbnb: An emerging platform of sharing economy based accommodation}

As the rapidly emerging and the global expansion of Airbnb, a plenty of research, especially since 2014, was conducted to explore this phenomenon and the mechanism beyond. As a new accommodation rental platform in the market, some studies sought to provide an evaluation of Airbnb. By applying descriptive statistics, Zekanović-Korona and Grzunov (2014) explored the structure of Airbnb users and the advantages and disadvantages of the platform. Similarly, a SWOT analysis was conducted with Airbnb to assess different dimensions of this business model, including the investment and financial strategies, legal issues on safety and tax, and its impacts on the other accommodation providers (Meleo, Romolini, \& De Marco, 2016). As the rapid development of Airbnb, its impacts on traditional hotels and online travel agents were identified. In particular, some studies investigated the competitive and substitute roles of Airbnb to the traditional hotels (Varma, Jukic, Pestek, Shultz, \& Nestorov, 2016; Guttentag \& Smith, 2017). Choi, Jung, Ryu, Do Kim, and Yoon (2015) found no impact of Airbnb on hotels' revenue performance with Korea as the context. However, Aznar, Sayeras, Rocafort, and Galiana (2017) argued that there was a positive relationship between the presence of Airbnb apartments and hotels' return on equity with Barcelona's hotel sector as the research target. In addition, the spatial patterns of hotels and Airbnb apartments were identified in a city destination (Gutiérrez, García-Palomares, Romanillos, \& Salas-Olmedo, 2017). Not limited to the economic and geographical impacts, the social, cultural and environmental impacts brought by Airbnb were also discussed by both academics and the public (Haines, 2016; Gurran \& Phibbs, 2017).

Focusing on the Airbnb platform, some studies were conducted to explore the characteristics of this platform and consumers' behavioral patterns on this platform. It 
is stated that belongingness and uniqueness are the essences of Airbnb concepts (Liu $\&$ Mattila, 2017). On the Airbnb platform, it is argued that being a Superhost means more reviews, higher ratings, and the higher willingness to spend more from the customers (Liang, Schuckert, Law, \& Chen, 2017). It is also interesting to note that, images uploaded to the Airbnb by the hosts, including the interior decoration of the property (Rahimi, Liu, \& Andris, 2016), hosts' personal photos (Ert, Fleischer, \& Magen, 2016) and even facial expression of the hosts (Fagerstrøm, Pawar, Sigurdsson, Foxall, \& Yani-de Soriano, 2017), play an important role in determining consumers' the booking behaviors on Airbnb. In addition, the determinants of prices on Airbnb are discussed to some extent. Factors such as host attributes, site and property attributes, amenities and services, rental rules, and online review ratings are stated to have a significant relationship with listings' prices on Airbnb platform (Li, Pan, Yang, \& Guo, 2016; Wang \& Nicolau, 2017).

\subsection{Determinants of online booking intention and behaviors}

Among the literature, sufficient studies explored the influencing factors which may affect customers' online booking intention or actual booking behavior. For example, research indicated that, online review comments and previous guests' recommendations played important roles in customers' decision-making process when booking hotels online (Sparks \& Browning, 2011; Tsao, Hsieh, Shih, \& Lin, 2015; Ladhari \& Michaud, 2015; Zhao, Wang, Guo, \& Law, 2015; Yu, Guo, Zhang, \& Zhao, 2016). Hotels' rating (Ladhari \& Michaud, 2015; Cezar \& Öğüt, 2016) and terms and conditions (Law \& Wong, 2010; Chen, Schwartz, \& Vargas, 2011) also influence customers' online purchase intention. Wang, Law, Guillet, Hung, and Fong (2015) and $\mathrm{Li}$ et al. (2016) argued that the quality of hotel online booking websites can be a predictor of the booking intention. With the basic understanding as a starting point, comparisons were conducted to discover the different preferences or booking patterns of different segments. For example, international and domestic customers were compared regarding their perceptions of the room price, review volume, location, brand, rules and conditions, ranking etc. and their impacts on hotel booking intension (Cezar \& Öğüt, 2012; 2016; Liu, Guillet, Xiao, \& Law, 2014).

The above review shows that the literature focusing on the determinants of online booking is dominant by the conventional hotels. However, the factors influencing the booking probabilities in the sharing economy are still mystic, but they may be different from the traditional hotels (Gutt \& Herrmann, 2015). As argued by Heo (2016), more attention should have been paid to the sharing economy when it has started to play a significant role in the industry. To fill in this gap, the booking determinants of the Airbnb properties in London are investigated by this study using a sequential Bayesian update approach. The methodology and data employed by this research are introduced in the following section.

\section{Data and Method}

The data used in the current study is drawn from a third-party website, Insideairbnb.com (n.d.), which consists of information that is publicly accessible on Airbnb.com, 31 variables are considered relevant to the current study. The variables considered as influential factors on the booking probability include the number of 
reviews, the price per person per night, the location of the listing, the neighboring conditions, and some other listing characteristics. London, UK is used as the focus of the current study because it is not only the second largest city in terms of the number of the listings, but also the city with the most up-to-date data at the time of data retrieval (March 2017). The dataset provides 365-day-ahead booking information for all the listings starting from the date of the data retrieval (5 March 2017). The listings with all 365 days unavailable are considered unrealistic and removed from the investigation. The listings have missing values in selected variables are omitted as well. 41124 listings remain in the dataset after the data cleaning. Although 365-dayahead booking information is avaiable from the dataset, tourists would start to worry about the likelihood of a sell out or a price raise of the room from 30 days before check-in (Chen \&Schwartz, 2008), a 35-days-ahead booking information is selected as the sample of this study. A binomial logistic model is adopted in estimating the effects of various factors on booking behavior. Due to the large volume of the data, Bayesian inference is adopted instead of frequentist (classical) inference.

\section{Findings and Discussions}

The mean value of posterier distribution of the time constant, $c_{t}$, captures the time effect on booking probability. Figure 1 shows the trend of the series $\left\{c_{t}, c_{t+1}, \cdots\right\}$. As expected, the effect of time on the booking probability decreases along time, with the weekends significantly higher than the weekdays.

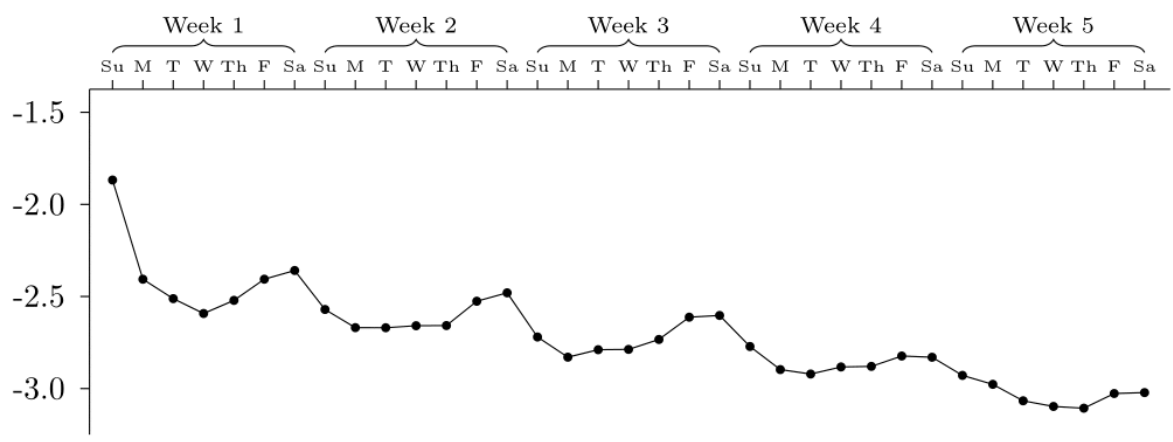

Figure 1 The mean estimation of time effect

Table 1 summarizes the posterior distributions of the parameters. The first column provides the variable descriptions. The second and third columns are the mean of posterior distributions and the change in odds ratios holding other variables fixed, respectively.

One Pound increase in the price per person per night would decrease the odds of the listings being booked by $1.16 \%$. The change in odds ratio are not very low on the number of neighboring listings and the number of available neighboring listings considering the maginitude of the two variables. The complicated rules may decrease 
the odds of the property being booked $(-8.34 \%)$, whereas the more introductions of the property by texts (in hundred words) and pictures may increase the odds by $5.45 \%$ and $20.08 \%$, respectively. Particularly, if the host mentions the space of the property, it would significantly improve the odds by $11.93 \%$. Holding all other factors fixed, being a Superhost in London will increase the odds of the listings being booked by $28.5 \%$. Furthermore, the disclosure of hosts' profile would improve the odds by $45.58 \%$, the verification of hosts' identity would increase the odds by $19.64 \%$.

In general, guests prefer large properties with more bedrooms and amenities. In particular, the offer of internet connection and kitchen would increase the odds of the property being booked by $35.29 \%$ and $26.76 \%$, respectively. The guests are sensitive about private space while booking Airbnb properties. Shared bedroom is less preferred $(-59.63 \%)$ while independent bathrooms are favored $(21.40 \%)$. In the case that the entire property is available as a whole, the odds or the property being booked would increase dramatically by $290.84 \%$. Extra charges, such as security deposit, cleaning fees, and the fees for extra person, would keep guests from booking $(-0.02 \%$, $-0.03 \%$, and $-0.93 \%$, respectively). In contrast, discounts on weekly or monthly bases or flexible refund policy would be more than welcome $(9.37 \%, 8.82 \%$, and $5.34 \%$, respectively). If a property can be booked instantly without contacting the host, its odds of being booked is increased by $33.23 \%$. In the case that guests' identity documents are requested by the host, the odds of the property being booked would decrease by $13.91 \%$. Online reviews are also crucial for guests' decision. One additional piece of review would increase the odds of the property being booked by $0.69 \%$.

Geographical convenience of the properties also plays an important role in attracting guests. The properties that are closer to Tube stations and city center are more popular in the market. In the current case of London, being away from the Tube station and the city center by $1 \mathrm{~km}$ will decrease the odds of the listings being booked by $7.62 \%$ and $6.71 \%$, respectively. The "theme" provided by the properties is also influential. In comparison with the plain properties without a "theme", the most popular "theme" is romantic (12.89\%) followed by family gathering (10.96\%). In contrast, the properties that are set for business or social occasions are less popular ($6.37 \%$ and $-3.55 \%$, respectively). In terms of the property type, house or townhouse are preferable by the guests $(9.89 \%)$, whereas bed \& breakfast are not $(-17.35 \%)$. Regarding the bed type, in comparison with other types, having pull-out sofas or real beds are considered as a desirable attribute $(28.55 \%)$ while having merely couches are $\operatorname{not}(-27.99 \%)$. 
Table 1 Summary of selected parameters

\begin{tabular}{|c|c|c|}
\hline Description & Mean & $\Delta$ Odds \\
\hline Price per capita & -0.0116 & $-1.16 \%$ \\
\hline Number of neighboring listings & 0.0001 & $0.01 \%$ \\
\hline Available neighboring listings & -0.0002 & $-0.02 \%$ \\
\hline Number of characters in rules & -0.0871 & $-8.34 \%$ \\
\hline Property Description & 0.0530 & $5.45 \%$ \\
\hline Description of space (Dummy) & 0.1127 & $11.93 \%$ \\
\hline Number of listing pictures & 0.1830 & $20.08 \%$ \\
\hline Super host (Dummy) & 0.2511 & $28.54 \%$ \\
\hline Host profile (Dummy) & 0.3756 & $45.58 \%$ \\
\hline Host verified ID (Dummy) & 0.1793 & $19.64 \%$ \\
\hline Number of Bedrooms & 0.0147 & $1.48 \%$ \\
\hline Number of Amenities & 0.0187 & $1.89 \%$ \\
\hline Number of bed per bedroom & -0.0984 & $-9.37 \%$ \\
\hline Bathroom per capita & 0.1940 & $21.40 \%$ \\
\hline Internet (Dummy) & 0.3023 & $35.29 \%$ \\
\hline Kitchen (Dummy) & 0.2371 & $26.76 \%$ \\
\hline Security deposit & -0.0002 & $-0.02 \%$ \\
\hline Cleaning fee & -0.0003 & $-0.03 \%$ \\
\hline Fee for extra person & -0.0094 & $-0.93 \%$ \\
\hline Weekly discount (Dummy) & 0.0896 & $9.37 \%$ \\
\hline Monthly discount (Dummy) & 0.0846 & $8.82 \%$ \\
\hline Instant reservation (Dummy) & 0.2869 & $33.23 \%$ \\
\hline Refund (Dummy) & 0.0520 & $5.34 \%$ \\
\hline Guest verification Required (Dummy) & -0.1497 & $-13.91 \%$ \\
\hline Number of Reviews & 0.0069 & $0.69 \%$ \\
\hline Distance to the nearest tube station & -0.0792 & $-7.62 \%$ \\
\hline Distance to city center & -0.0694 & $-6.71 \%$ \\
\hline \multicolumn{3}{|l|}{ Property function (Group of dummies) } \\
\hline None & Benchmark & \\
\hline Romantic & 0.1214 & $12.89 \%$ \\
\hline Family & 0.1040 & $10.96 \%$ \\
\hline Business & -0.0659 & $-6.37 \%$ \\
\hline Social & -0.0361 & $-3.55 \%$ \\
\hline \multicolumn{3}{|l|}{ Property type (Group of dummies) } \\
\hline Others & Benchmark & \\
\hline Apartment & 0.0175 & $1.77 \%$ \\
\hline House \& Townhouse & 0.0943 & $9.89 \%$ \\
\hline Bed \& Breakfast & -0.1905 & $-17.35 \%$ \\
\hline \multicolumn{3}{|l|}{ Room Type (Group of dummies) } \\
\hline Shared room & Benchmark & \\
\hline Private room & 0.4677 & $59.63 \%$ \\
\hline Entire property & 1.3632 & $290.84 \%$ \\
\hline \multicolumn{3}{|l|}{ Bed Type (Group of dummies) } \\
\hline Others & Benchmark & \\
\hline Couch & -0.3284 & $-27.99 \%$ \\
\hline Pull-out Sofa/Real bed & 0.2512 & $28.55 \%$ \\
\hline
\end{tabular}




\section{Conclusion}

A binomial logistic model is estimated by sequential Bayesian updating method in the current study to investigate the determinants of the booking probabilities of Airbnb properties in London. The results show that in addition to the market factors such as the price and the spillover effects of neighboring properties, the attributes of the property play a very important role in influencing the probability of the property being booked. These research findings would be beneficial for the existing and potential Airbnb hosts in their decision-making process. Based on the current situation of the markets and the properties, the hosts can reallocate limited resources from less important factors to more important factors in order to achieve a better booking status. The results of the current study can also be used by industrial management organizations to predict potential occupancy rate as well as potential revenue 


\section{References}

Airbnb (2017). About us-Airbnb. (n.d.). Retrived from https://www.airbnb.com/about/aboutus.

Aznar, J. P., Sayeras, J. M., Rocafort, A., \& Galiana, J. (2017). The irruption of Airbnb and its effects on hotel profitability: An analysis of Barcelona's hotel sector. Intangible Capital, 13(1).

Cezar, A., \& Ögüt, H. (2012). The determinants of domestic and international visitors' online hotel booking. Procedia-Social and Behavioral Sciences, 58, 971-979.

Cezar, A., \& Öğüt, H. (2016). Analyzing conversion rates in online hotel booking: The role of customer reviews, recommendations and rank order in search listings. International Journal of Contemporary Hospitality Management, 28(2), 286-304.

Chen, C. C., Schwartz, Z., \& Vargas, P. (2011). The search for the best deal: How hotel cancellation policies affect the search and booking decisions of deal-seeking customers. International Journal of Hospitality Management, 30(1), 129-135.

Chen, C. C., \& Schwartz, Z. (2008). Timing matters: Travelers' advanced-booking expectations and decisions. Journal of Travel Research, 47(1), 35-42.

Choi, K. H., Jung, J. H., Ryu, S. Y., Do Kim, S., \& Yoon, S. M. (2015). The relationship between Airbnb and the hotel revenue: in the case of Korea. Indian Journal of Science and Technology, 8(26).

Ert, E., Fleischer, A., \& Magen, N. (2016). Trust and reputation in the sharing economy: The role of personal photos in Airbnb. Tourism Management, 55, 62-73.

Fagerstrøm, A., Pawar, S., Sigurdsson, V., Foxall, G. R., \& Yani-de-Soriano, M. (2017). That personal profile image might jeopardize your rental opportunity! On the relative impact of the seller's facial expressions upon buying behavior on Airbnb ${ }^{\mathrm{TM}}$. Computers in Human Behavior, 72, 123-131.

Gurran, N., \& Phibbs, P. (2017). When Tourists Move In: How Should Urban Planners Respond to Airbnb?. Journal of the American Planning Association, 83(1), 80-92.

Gutiérrez, J., García-Palomares, J. C., Romanillos, G., \& Salas-Olmedo, M. H. (2017). The eruption of Airbnb in tourist cities: Comparing spatial patterns of hotels and peer-to-peer accommodation in Barcelona. Tourism Management, 62, 278-291.

Gutt, D. and Herrmann, P. (2015). Sharing means caring? Hosts' price reaction to rating visibility. In ECIS 2015 Research-in-Progress Papers (Paper 54). Retrieved from http://aisel.aisnet.org/ecis2015_rip/54/.

Guttentag, D. A., \& Smith, S. L. (2017). Assessing Airbnb as a disruptive innovation relative to hotels: Substitution and comparative performance expectations. International Journal of Hospitality Management, 64, 1-10.

Haines, G. (2016). Amsterdam has become 'unlivable' as residents fight back to stop 'Disneyfication' of city, in The Telegraph, retrieved on August 29, from http://www.telegraph.co.uk/travel/destinations/ europe/netherlands/amsterdam/articles/how-amsterdam-is-tackling-disneyfication/

Heo, C. Y. (2016). Sharing economy and prospects in tourism research. Annals of Tourism Research, 58(C), 166-170.

Insideairbnb.com. (n.d.). Inside Airbnb. Get the data. Retrieved from http://insideairbnb.com/get-thedata. html (21 Aug 2017)

Ladhari, R., \& Michaud, M. (2015). eWOM effects on hotel booking intentions, attitudes, trust, and website perceptions. International Journal of Hospitality Management, 46, 36-45.

Law, R., \& Wong, R. (2010). Analysing room rates and terms and conditions for the online booking of hotel rooms. Asia Pacific Journal of Tourism Research, 15(1), 43-56. 
Li, Y., Pan, Q., Yang, T., \& Guo, L. (2016, July). Reasonable price recommendation on Airbnb using Multi-Scale clustering. In Control Conference (CCC), 2016 35th Chinese (pp. 7038-7041). IEEE.

Liang, S., Schuckert, M., Law, R., \& Chen, C. C. (2017). Be a "Superhost": The importance of badge systems for peer-to-peer rental accommodations. Tourism Management, 60, 454465.

Liu, S. Q., \& Mattila, A. S. (2017). Airbnb: Online targeted advertising, sense of power, and consumer decisions. International Journal of Hospitality Management, 60 , 33-41.

Liu, W., Guillet, B. D., Xiao, Q., \& Law, R. (2014). Globalization or localization of consumer preferences: The case of hotel room booking. Tourism Management, 41, 148-157.

Meleo, L., Romolini, A., \& De Marco, M. (2016, May). The Sharing Economy Revolution and Peer-to-peer Online Platforms. The Case of Airbnb. In International Conference on Exploring Services Science (pp. 561-570). Springer, Cham.

Morgan, B., \& Kuch, D. (2015). Radical transactionalism: Legal consciousness, diverse economies, and the sharing economy. Journal of Law and Society, 42 (4), 556-587.

OpenStreetMap.org. (n.d.). List of London underground stations. Retrieved from http://wiki.openstreetmap .org/wiki/List_of_London_Underground_stations (21 Aug 2017)

Orsi, J. (2013). The sharing economy just got real. Shareable.net.

Rahimi, S., Liu, X., \& Andris, C. (2016, October). Hidden style in the city: an analysis of geolocated airbnb rental images in ten major cities. In Proceedings of the 2nd ACM SIGSPATIAL Workshop on Smart Cities and Urban Analytics (p. 7). ACM.

Sparks, B. A., \& Browning, V. (2011). The impact of online reviews on hotel booking intentions and perception of trust. Tourism management, 32(6), 1310-1323.

Tsao, W. C., Hsieh, M. T., Shih, L. W., \& Lin, T. M. (2015). Compliance with eWOM: The influence of hotel reviews on booking intention from the perspective of consumer conformity. International Journal of Hospitality Management, 46, 99-111.

Varma, A., Jukic, N., Pestek, A., Shultz, C. J., \& Nestorov, S. (2016). Airbnb: Exciting innovation or passing fad?. Tourism Management Perspectives, 20, 228-237.

Wang, D., \& Nicolau, J. L. (2017). Price determinants of sharing economy based accommodation rental: A study of listings from 33 cities on Airbnb. com. International Journal of Hospitality Management, 62, 120-131.

Wang, L., Law, R., Guillet, B. D., Hung, K., \& Fong, D. K. C. (2015). Impact of hotel website quality on online booking intentions: eTrust as a mediator. International Journal of Hospitality Management, 47, 108-115.

Yang, Y., Wong, K. K., \& Wang, T. (2012). How do hotels choose their location? Evidence from hotels in Beijing. International Journal of Hospitality Management, 31(3), 675-685.

Yu, Y., Guo, X., Zhang, Y., \& Zhao, H. (2016). Online Review Impacts on Hotel Online Booking Decision.

Zekanovic-Korona, L., \& Grzunov, J. (2014, May). Evaluation of shared digital economy adoption: Case of Airbnb. In Information and Communication Technology, Electronics and Microelectronics (MIPRO), 2014 37th International Convention on (pp. 1574-1579). IEEE.

Zhao, X., Wang, L., Guo, X., \& Law, R. (2015). The influence of online reviews to online hotel booking intentions. International Journal of Contemporary Hospitality Management, 27(6), 1343-1364. 